\title{
Investments in the Development of Human Capital of Mining Industry
}

\author{
Lyudmila Khayrulina $^{1}$, Darya Savrasova ${ }^{1}$, and Margarita Zhidkova ${ }^{2,{ }^{*}}$ \\ ${ }^{1}$ Financial University under the Government of the Russian Federation, Omsk Branch, 644099 \\ Partizanskaya st. 6, Omsk, Russia \\ ${ }^{2}$ Moscow Automobile and Road Construction State Technical University (MADI), 125319 \\ Leningradsky prospect 64, Moscow, Russia
}

\begin{abstract}
In this paper, the authors substantiate the need for a flexible approach to investment management in the development of human capital in the mining industry. The assessment of qualitative and quantitative indicators characterizing the state and level of development of human capital in the mining industry is given. The most relevant types of investments in the development of human capital in the mining industry are considered. The problem areas of the development of human capital in the mining industry are identified. The actual forms of investment in the development of human capital in the mining industry are identified. The measures to reduce the risks of investment in the development of human capital in the mining industry are recommended.
\end{abstract}

\section{Introduction}

The conditions of technological revolution and the uncertainty of geopolitical situation determine the need for intensive development of human capital in the Russian mining industry. The introduction of digital technologies to ensure transparency of mining operations and control over them, the rise of degree of raw materials processing in the places of their extraction makes investment in human capital inevitable in order to maintain sustainable development.

Human capital is the productive ability of an individual. It is determined by the age of the individual, the level of his/her education, physical and emotional state of health. As the economic category, "human capital" reflects the creative ability of the individual, which forms, uses, redistributes and reproduces the society, family, organization and the individual himself. Human capital cannot be separated from its carrier - the individual. The company in fact leases this economic resource as a factor of production. The ability of human capital to create value added determines its importance for the enterprise, and for the individual it means the level of the income. With certain investments, human capital has the ability to increase its value and, thus, acquire the ability to generate income through innovative types and methods of activity. Human capital implements the potentially qualities and abilities of a person, as well as the qualities and abilities acquired in the process of training and work.

\footnotetext{
${ }^{*}$ Corresponding author: $\underline{\text { info@madi.ru }}$
} 


\section{Materials and Methods}

Human capital development management is carried out by enterprise executives and human resources management services [3-5]. The development of human capital in mining enterprises requires regular investments in education, health and staff mobility. Such investments are a focused activity of the investor aimed at increasing the productivity of the employee, which, in turn, creates added value for the enterprise. In this case, the investor may be [5-9]:

- an employee who incurs expenses for his education, medical services and relocation from places with relatively low productivity to places with relatively high productivity in order to improve the quality of life;

- the employer, which incurs expenses for the advanced training of employees, the prevention of their diseases, as well as relocation (moving the employee to another region, to the place where the employer needs it);

- a state financing health care, education and measures to reduce unemployment.

All these three investors are deeply interested in the human capital development, striving to get the maximum result at the lowest cost.

At the same time, investments in human capital are always risky, since the person is not the property of the enterprise, and sells his/her labor to the employer for a certain time. There is a likelihood of his dismissal, loss of working capacity, reduced motivation for work or even death. The magnitude of this probability is largely determined by the personnel policy of the mining enterprise: providing workers with comfortable and safe working conditions, decent wages, interesting work, and creating a normal socio-psychological climate in the organization [10-13]. The development of human capital requires considerable efforts and costs from the employee himself, the enterprise and society as a whole.

\section{Results and Discussion}

The human capital of mining enterprises is characterized by quantitative and qualitative indicators. In Russia, 1,658 thousand people work in the industries engaged in exploration, production, and primary processing of minerals (according to data for 2018). Dynamics of changes in the number of people employed in the Russian economy as a whole, including mining operations for 2005-2018, are presented in Tab. 1 [1].

Table 1. Dynamics of changes in the number of people employed in the Russian economy for 20052018.

\begin{tabular}{|l|c|c|c|c|c|c|c|}
\hline Indicators & 2005 & 2010 & 2014 & 2015 & 2016 & 2017 & 2018 \\
\hline $\begin{array}{l}\text { Employed total, thousand } \\
\text { people }\end{array}$ & 68339 & 69933 & 71539 & 72323 & 72393 & 72316 & 72531 \\
\hline $\begin{array}{l}\text { Including: engaged in } \\
\text { mining, thousand people }\end{array}$ & 1223 & 1406 & 1526 & 1505 & 1579 & 1565 & 1658 \\
\hline$\%$ of total employed & 1.79 & 2.01 & 2.13 & 2.08 & 2.18 & 2.16 & 2.28 \\
\hline
\end{tabular}

As follows from the data in Table 1, the share of people engaged in mining in the total number of employed in Russia increased from $1.79 \%$ in 2005 to $2.28 \%$ in 2018 . An interesting fact is that the gender structure of those engaged in mining operations is changing towards an increase in the already predominant proportion of men from $77.84 \%$ (2005) to $82.44 \%$ (2018).

The main qualitative characteristic of the human capital of an enterprise is the level of qualification of employees, determined by the level of education and work experience. At the same time, the main asset of human capital is education, which helps to increase labor 
productivity. The number of people engaged in mining in Russia by education level for 2016 and 2018 is presented in Tab. 2 [1].

Table 2. The number of people engaged in mining in Russia by education level for 2016, 2018.

\begin{tabular}{|l|c|c|c|c|}
\hline \multicolumn{1}{|c|}{ Indicators } & Total & Higher & \multicolumn{2}{c|}{ Secondary vocational } \\
\cline { 3 - 5 } & & $\begin{array}{c}\text { According to the } \\
\text { mid-level training } \\
\text { program }\end{array}$ & $\begin{array}{c}\text { According to the } \\
\text { training program for } \\
\text { skilled workers } \\
\text { (employees) }\end{array}$ \\
\hline $\begin{array}{l}\text { Employed in 2016, } \\
\text { thousand people }\end{array}$ & 1579 & 409 & 401 & 422 \\
\hline$\%$ & 100 & 25.9 & 25.4 & 26.7 \\
\hline $\begin{array}{l}\text { Employed in 2018, } \\
\text { thousand people }\end{array}$ & 1658 & 476 & 420 & 455 \\
\hline$\%$ & 100 & 28.7 & 25.3 & 27.4 \\
\hline
\end{tabular}

An analysis of the dynamics of the level of education of personnel in Russian mining enterprises demonstrates an increase in the share with higher education from $25.9 \%$ in 2016 to $28.7 \%$ in 2018 , and a decrease in the share of the number of workers with secondary education by $4 \%$. The number of people engaged in mining operations in Russia by experience in 2016 and 2018 is presented in Tab. 3 [1,2].

Table 3. The number of people engaged in mining in Russia by experience in 2016, 2018.

\begin{tabular}{|c|c|c|c|c|c|c|c|}
\hline \multirow[t]{2}{*}{ Indicators } & \multirow{2}{*}{ Total } & \multicolumn{6}{|c|}{ Including work experience } \\
\hline & & $\begin{array}{l}\text { less than } \\
1 \text { month }\end{array}$ & $\begin{array}{c}\text { from } 1 \\
\text { month to } \\
1 \text { year }\end{array}$ & $\begin{array}{c}\text { from } 1 \\
\text { year to } 3 \\
\text { years }\end{array}$ & $\begin{array}{c}\text { from } 3 \\
\text { year to } 5 \\
\text { years }\end{array}$ & $\begin{array}{c}\text { from } \\
5 \text { year to } \\
10 \text { years }\end{array}$ & $\begin{array}{l}10 \text { years } \\
\text { or more }\end{array}$ \\
\hline $\begin{array}{l}\text { The number of } \\
2018, \\
\text { thousand } \\
\text { people. }\end{array}$ & 1658 & 10 & 109 & 216 & 234 & 452 & 638 \\
\hline$\%$ & 100 & 0.6 & 6.6 & 13.0 & 14.1 & 27.3 & 38.5 \\
\hline $\begin{array}{l}\text { The number of } \\
2016 \text {, } \\
\text { thousand } \\
\text { people. }\end{array}$ & 1579 & 9 & 109 & 216 & 239 & 395 & 611 \\
\hline$\%$ & 100 & 0.6 & 6.9 & 13.7 & 15.1 & 25.0 & 38.7 \\
\hline
\end{tabular}

As follows from the data in Table 3, in 2018 the share of workers with work experience from 1 to 3 years was $13 \%$, from 3 to 5 years $-14.1 \%$, from 5 to 10 years $-27.3 \%$, and more than 10 years $-38.5 \%$. Tab. 4 presents the number of people engaged in mining operations by age groups for 2018 [2].

Table 4. Number of employees in the Russian economy by age groups, 2018.

\begin{tabular}{|l|c|c|c|c|c|c|c|c|c|}
\hline \multicolumn{1}{|c|}{ Indicators } & \multirow{2}{*}{$\begin{array}{c}\text { Total, } \\
\text { thous.people }\end{array}$} & \multicolumn{9}{|c|}{ Including age, years } \\
\cline { 3 - 10 } & & $\mathbf{2 0 - 2 9}$ & $\mathbf{3 0 - 3 4}$ & $\begin{array}{c}\mathbf{3 5 -} \\
\mathbf{3 9}\end{array}$ & $\mathbf{4 0 - 4 9}$ & $\mathbf{5 0 - 5 9}$ & $\begin{array}{c}\mathbf{6 0 -} \\
\mathbf{6 4}\end{array}$ & $\begin{array}{c}\mathbf{6 5 -} \\
\mathbf{6 9}\end{array}$ & $\begin{array}{c}\mathbf{7 0} \text { and } \\
\text { older }\end{array}$ \\
\hline $\begin{array}{l}\text { Employed - } \\
\text { total, thousand } \\
\text { people }\end{array}$ & 72532 & 1375 & 10882 & 9951 & 17697 & 15553 & 3045 & 980 & 299 \\
\hline$\%$ & & 3 & & & & & & & \\
\hline $\begin{array}{l}\text { Engaged in } \\
\text { mining } \\
\text { operations, } \\
\text { thousand } \\
\text { people }\end{array}$ & 100 & 19.0 & 15.0 & 13.7 & 24.4 & 21.4 & 4.2 & 1.4 & 0.4 \\
\hline$\%$ & & 322 & 283 & 245 & 416 & 346 & 37 & 7 & 7 \\
\hline
\end{tabular}


From table 4 it follows that the average age of workers engaged in mining is 40.1 years, which is 1 year less than the average age of workers employed in the Russian economy. Moreover, if we compare the dynamics of changes in the number of employees by age groups in the Russian economy as a whole and in the mining industry, we can see that the share of workers at the peak of working age between 20 and 50 years old is higher in the industry compared to the national indicators.

The development of the human capital of an organization occurs, first, due to investments in training, retraining and advanced training of personnel. According to Rosstat, the number of employees engaged in mining operations trained in 2016 was 342,275 people, which is $21.7 \%$ of the total number of employees in the industry. 92248 people received additional professional education: of these, 16,641 people - under professional retraining programs, 77,376 people - under advanced training, 117 people received additional education abroad.

In 2016, 173,346 people went through vocational training: of these, according to vocational training programs in the professions of workers and positions of employees 37,049 people; retraining of workers, employees - 32,097 people; advanced training of workers, office workers - 108651 people. Directly in the organization, 59016 people passed vocational training, which is $34 \%$ of those who passed vocational training.

Education in the main professional educational programs was received by 7,453 people: secondary vocational education in the training programs for skilled workers and employees - 1,815 people, secondary vocational education in the training programs for mid-level specialists $-1,661$ people, higher education $-3,977$ people. Training in the form of shortterm courses, professional trainings, and mentoring were completed by 90966 people, which is $26.6 \%$ of the total number of people trained in 2016 in the industry [1]. Investments in the human capital of the mining industry can be estimated on the basis of data from a sample study of Rosstat, presented in Tab. 5 [1].

Table 5. The structure of labor costs in the Russian economy for 2013, 2017.

\begin{tabular}{|c|c|c|c|c|c|c|c|c|}
\hline \multirow[t]{3}{*}{ Indicators } & \multirow{3}{*}{ 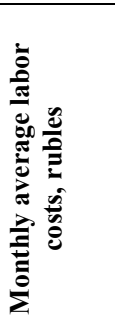 } & \multicolumn{7}{|c|}{ Including, percent } \\
\hline & & \multirow[b]{2}{*}{ 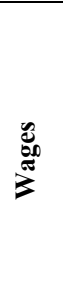 } & \multicolumn{3}{|c|}{ From wages } & \multicolumn{2}{|c|}{$\begin{array}{c}\text { Social } \\
\text { protection } \\
\text { expenses }\end{array}$} & \multirow{2}{*}{ 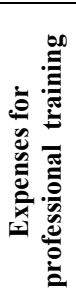 } \\
\hline & & & 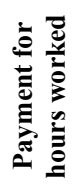 & 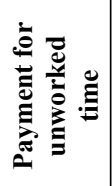 & 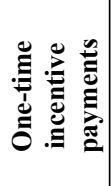 & 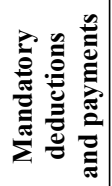 & 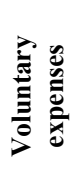 & \\
\hline Total 2013 & 45870.2 & 75.1 & 63.3 & 6.7 & 4.7 & 19.7 & 1.7 & 0.3 \\
\hline $\begin{array}{l}\text { Mining } \\
2013\end{array}$ & 76525.5 & 72.3 & 56.4 & 8.8 & 6.5 & 19.1 & 3.2 & 0.4 \\
\hline $\begin{array}{l}\text { Total } \\
2017\end{array}$ & 59902.2 & 75.0 & 63.4 & 6.4 & 4.8 & 20.7 & 1.4 & 0.3 \\
\hline $\begin{array}{l}\text { Mining } \\
2017\end{array}$ & 104076.1 & 71.7 & 56.1 & 8.3 & 6.7 & 20.0 & 2.5 & 0.4 \\
\hline
\end{tabular}

As can be seen from table 5, the structure of labor costs does not significantly change either in the economy as a whole, or in mining, in particular. Investments in training of human resources in the mining industry are $0.1 \%$ higher than in the economy as a whole. An analysis of Rosstat data shows that investments in the training of personnel in enterprises of almost all selectively studied types of economic activity are at the level of 1-4\% of the average monthly labor costs. In absolute terms, the average annual investment in the training of one employee of mining enterprises in 2013 amounted to 3,673 rubles, in $2017-4,995$ rubles. In the future, the growth of investments aimed at training employees of mining companies is 
forecasted. The following types of economic activity in Russia are leaders in investments in personnel training: air and space transport $-1.6 \%$; production of coke and petroleum products $-0.9 \%$.

The need for investment in the development of human capital for mining companies is growing every year. A massive generational shift is expected in Russian mining industry. According to forecasts, 350 thousand people will retire in the next 10 years, which will be $20 \%$ of the total labor resources of this industry. The vacancies will be filled by young specialists who are currently studying in areas related to mining.

According to the Federal State Statistics Service of Russian Federation, the graduation of bachelors, specialists and masters from higher schools and scientific organizations in the areas of training "applied geology, mining, oil and gas and geodesy" amounted to 23.2 thousand people in 2017, in 2018 - 23.2 thousand people Graduation of mid-level specialists in the field of "applied geology", "mining", "oil and gas" and "geodesy" in 2016 - 18.8 thousand people, 2017 - 20.6 thousand people, $2018-22.5$ thousand people. It can be seen that there is a tendency to increase the output of the number of mid-level specialists. The graduation of skilled workers and employees in the professions "applied geology", "mining", "oil and gas" and "geodesy" in 2016 - 2.1 thousand people, in 2017 - 2.1 thousand people, in $2018-1.9$ thousand people. As you can see, the release of the number of workers and employees is an order of magnitude lower than the release of the number of mid-level specialists [2].

The actual direction continues to be the creation of training centers for in-company training based on the large mining companies [3]. Training employees within working space, taking into account the specifics of work within the corporate culture was organized. This form of training continues to be an important factor in the long-term success of mining enterprises. A striking example is the Technical University of UMMC, opened in 2013, which is part of the Ural Mining and Metallurgical Company (Russian Mining and Metallurgical Holding). About 12 thousand people study at the UMMC Technical University annually. These are students from the cities of the Company's presence, as well as engineers and managers at all levels [4].

The training centre (TC) of the personnel department in the subdivision of Uchalinsky Ore Mining and Processing Industrial Complex JSC, organizes the training of enterprise personnel in vocational training programs. In addition, the employees of the enterprise improve their qualifications in the corporate educational institution - the Technical University of UMMC in full-time, part-time, distance learning. Every year, over 300 people undergo training, production and pre-graduation internships in the divisions of the enterprise. These are students of the Uchalinsky College of Mining, G.I. Nosov Magnitogorsk State Technical University, Ural State Mining University (Ekaterinburg), South Ural State University (Chelyabinsk), etc. [5]. Attracting mining specialists is not an easy task for personnel services of mining enterprises. On the job search site russia.trud.com/jobs in the section "Mining in Russia", about 1,500 vacancies are reflected daily. Engineering design, with all its various disciplines, is a highly demanded and generally well-paid position in the mining sector: head of the express laboratory gains 130,000 rubles; chief project engineer 120000 rubles; leading mining engineer $-80,000$ rubles.

A tax statistics report published by the Russian Tax Administration in early 2020 ranked mining engineers among the highest paid specialists. Despite the attractiveness of high salaries, the managerial functions of such specialists are associated with a large workload and additional responsibility for providing strategic management of complex operations; therefore, there is a significant shortage of mining engineers in the labor market. The mining industry is an extremely diverse work industry, which offers positions in many areas: there are positions for specialists such as electricians, welders, carpenters, mechanics, etc. Next are positions for operators, drivers, miners, explosive crews, etc. There are also positions for 
engineers, geologists, environmental and safety specialists, etc. As a rule, high demands are placed on applicants for the level of education and work experience in the mining industry.

In the mining industry, where production sites are often located in remote regions, companies prefer to invest in the relocation of a ready-made specialist than to grow their own. In addition, the need for investment in staff development is due to changes in the nature of labor relations associated with the growth of the economy of free earnings. This leads to the fact that the personnel strategies of mining companies are forced to plan training for employees working under fixed-term contracts, setting performance indicators for them and providing them with opportunities for adaptation and development. The desire to retain key specialists, reduce the risk of dismissal, encourages mining companies to invest in the wellbeing of their employees, including their physical, mental, financial and emotional state. The traditional costs of decent working conditions, medical care, and housing are complemented by new areas of investment. In modern conditions, much more attention needs to be paid to ensuring the right balance between work and the personal life of employees, preventing physical and mental exhaustion from work 24 hours a day. For this purpose, leading companies use wearable devices to monitor employees' physical health indicators, and organize fitness and stress management programs. It is necessary to develop effective strategies for retaining young professionals that provide their motivation: choosing the preferred form of remuneration, introducing personalized and flexible methods of remuneration, providing the new generation with the opportunity to gain real experience as a result of creative business trips and participation in interesting events.

\section{Conclusion}

Today, one of the factors holding back investments in the development of human capital in the mining industry is the presence of significant investment risks and not always a high level of risk management. An urgent problem for mining companies is the careful study of effective areas of investment in human capital. The development of human capital in mining enterprises occurs:

According to the authors, in order to ensure flexible management of investments in the development of human capital in the mining industry, it is necessary on a regular basis:

- first, due to investments in training, retraining and advanced training of personnel; the second - due to the costs of attracting and relocating employees of the required qualifications; third - due to the costs of ensuring the physical and emotional health of employees.

- monitor the state of quantitative and qualitative characteristics of the human capital of the mining industry;

- evaluate the problems of human capital development in the mining industry;

- on the basis of the analysis carried out, determine the actual directions of investments in the development of human capital in the mining industry;

- develop measures to reduce the risks of investment in the development of human capital in the mining industry.

Summing up, we note that a flexible approach to managing investments in the development of human capital creates the conditions for achieving the strategic development goals of mining companies.

\section{References}

1. Rosstat, Labour and Employment in Russia. 2017 (Rosstat Pub., Moscow, 2017)

2. Rosstat, Labour and Employment in Russia. 2017 (Rosstat Pub., Moscow, 2017)

3. V. S. Velikanov, Mining Industry, 4:122, 36 (2015) 
4. UMMC Technical University Website. URL: https://tu-ugmk.com/

5. Ugra Mining and Processing Plant Website. URL: http://www.ugok.ru/ru/social_responsibility/

6. V. Frolova, O. Dolina, T. Shpilkina, E3S Web Conf., 105, 01054 (2019)

7. O. Miliushenko, A. Kovalev, M. Zhidkova, E3S Web Conf., 105, 04046 (2019)

8. O. Kalenov, S. Kukushkin, R. Kamanina, E3S Web Conf., 105, 04028 (2019)

9. S. Kukushkin, O. Kalenov, E3S Web Conf., 105, 04022 (2019)

10. V. Frolova, O. Dolina, T. Shpilkina, E3S Web Conf., 21, 04018 (2017)

11. T. Skryl, E. Shavina, E. Dotsenko, E3S Web Conf., 105, 04049 (2019)

12. O. Borisova, V. Frolova, L. Artamonova, E3S Web Conf., 105, 04047 (2019)

13. Dotsenko, E., Ezdina, E3S Web Conf., 15, 04012 (2017) 